\title{
Utilization of GPS data in the effort of Mineral Identification in Granite Rocks Using X-Ray Diffraction in Samadua District, South Aceh
}

\author{
Bakruddin ${ }^{1, *}$, Safridatul Audah,2 \\ ${ }^{1}$ South Aceh Polytecnic, Jl. Reklamasi Pantai, Tapaktuan and 23711, Indonesia \\ ${ }^{2}$ South Aceh Polytecnic, Jl. Reklamasi Pantai, Tapaktuan and 23711, Indonesia
}

'bakry.klt@gmail.com*; ${ }^{*}$ safridatul@yahoo.co.id

\begin{tabular}{ll} 
ARTICLE INFO & ABSTRACT \\
\hline $\begin{array}{l}\text { Article history: } \\
\text { Accepted }\end{array}$ & $\begin{array}{l}\text { South Aceh has abundant natural resources, one of which is granite } \\
\text { rock, at Kutablang Village and Lubuk Layu Village, Samadua }\end{array}$ \\
& $\begin{array}{l}\text { District. This research discusses about minerals phases using the X- } \\
\text { Ray Diffraction method. The results obtained in the phase of the }\end{array}$ \\
& granite constituent minerals from Kutablang Village were \\
Keywords: & C16AlCIN16S4, O2Si, and F15Mo5O15Rb15, and the phases of the \\
Aceh Selatan & constituent minerals from Lubuk Layu Village were O2Si, \\
Kecamatan Samadua & F15Mo5O15Rb15 and La2Mo2O9.
\end{tabular}

\section{Introduction}

Granite is an intrusive igneous rock that includes silica (Sio2) compounds or pure silica in two forms, quartz and cristobalite, this volcanic rock is the most common rock in the earth formed by the magma process which is cooled slowly [1]. Based on granitic structure and holocrystalline structure, granite rocks consist of quartz and feldspar elements, while other minerals in small amounts such as biotite, muscovite, hornblende, and pyroxene [2].

South Aceh Regency has abundant geological resource potential, both metal minerals and nonmetallic minerals, such as iron ore, gold, copper, quartz sand, clay, marble and granite [3].

Granite is one of the natural resources that can be used to support various human needs and widely used as a base material in the industrial sector [4]. The granite mining industry in the last 10 years is the most promising business, with production growth in the world at an average of $6 \%$ per year, and sales reaching 6 billion dollars per year [5].

However, the utilization and processing of granite rocks in South Aceh is still very minimal, this is due to limited knowledge and research in the field to obtain high-quality and high-value granite stones. Some studies use X-ray Diffraction (XRD) as a method that is able to analyze the types and properties of minerals by looking at the diffraction patterns produced. Therefore it is necessary to do research on granite rocks in Samadua District by identifying the mineral phases in these rocks.

\section{Related Studies}

Several studies related to this research are research Bajili A., dkk (2014)mineral characterization using X-ray Diffraction (XRD) on granite rocks has a mineral phase Kuarsa, Ortoklas, Albite, Magnetit, Thorit, Ilminit, Hornblende, Kaolinite, Muscovite, and Sodalite. Then in research Oktamuliani S., dkk (2015) mentions based on testing using X-ray Diffraction (XRD) carried out on rock Geopark Merangin which is a mineral phase Quartz, Anorthoclase which is included in the 
mineral class K-Feldspar and Muskovit. Juliansyah, dkk (2015), granite minerals contain $\mathrm{Ca}$ and $\mathrm{Si}$ as the most content element in the form of compounds $\mathrm{SiO} 2, \mathrm{Ca}, \mathrm{Co} 3$, dan $\mathrm{CaCl} 2$.

\section{Method of the Research}

In this research has done by several stages, which are literature studies, sampling, sample preparation, laboratory tests, and results analysis. The stages which are:

\section{A. Sampling of Rock}

Sampling of granite rock is done by directly survey at the field in two different locations, which are Village of Kutablang and the Village of Lubuk Layu, District of Samadua. Thereafter, to determine the coordinate's position of the sampling using the Global Positioning System handheld (GPS). The advantages of using GPS in this study are its ability to map direct observation points or actual location points and then digitally process it to become a map. The location rock of sampling can be seen in Figure 1 below.

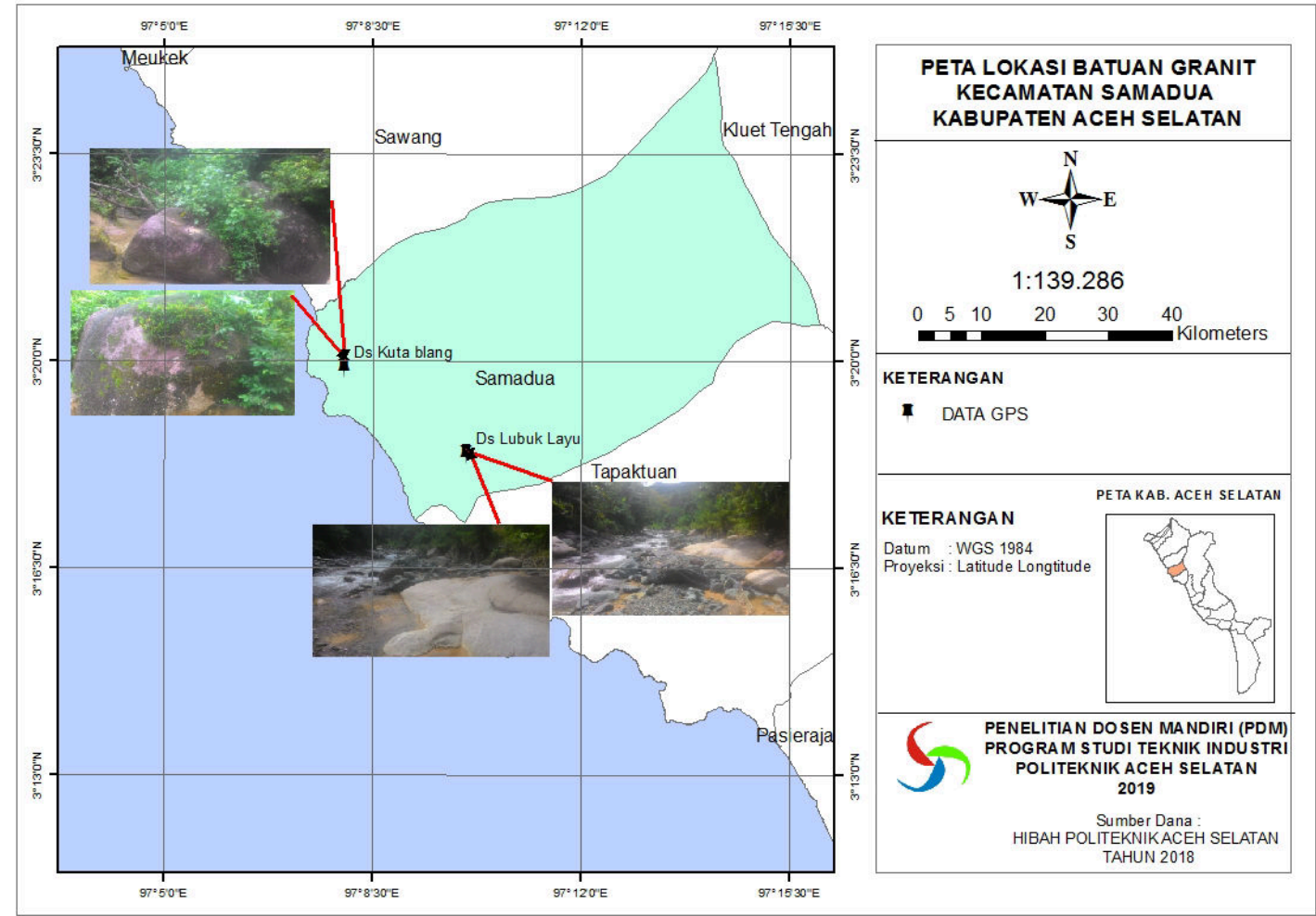

Gambar 1. Map's Location of Granit rocks at Samadua District, South Aceh

\section{B. Preparation of Rock Samples}

Sample preparation is to prepare rock samples in the form of small piece and then made into small granules (powder). The granite rock samples from each location are shown in Figure 2 and Figure 3 the following. 


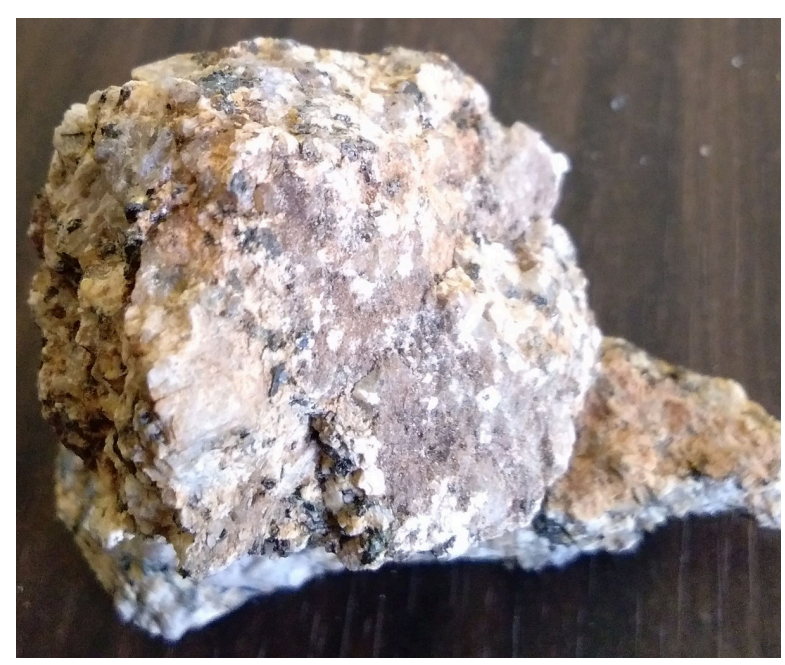

Figure 2. Samples of Granite Rocks from Kuta Blang Village

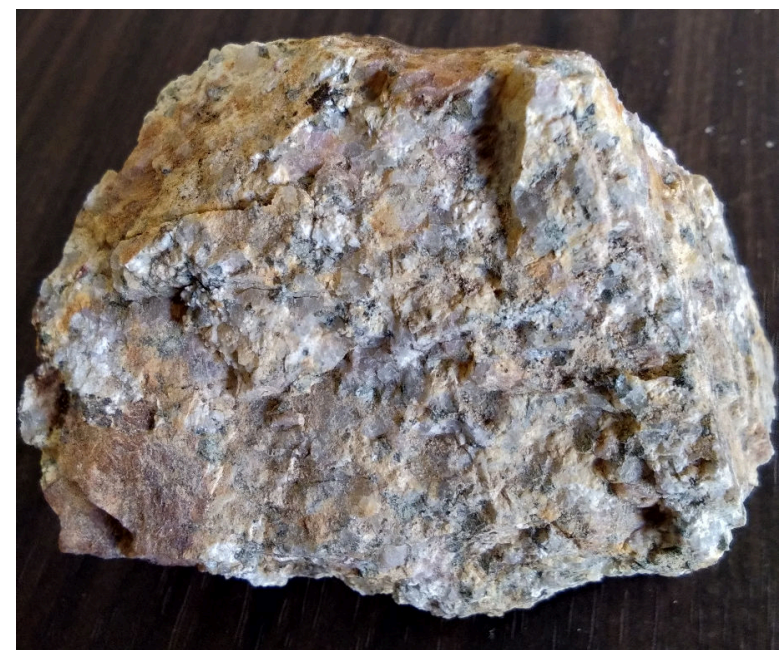

Figure 3. Samples of Granite Rocks from Lubuk Layu Village

\section{Test of Laboratory}

The laboratory test is to test the sample of rock to obtain the mineral phase composition by using a X-ray Difrractometer (XRD) machine with the Shimadzu X-ray diffraction technique, Co-K $\alpha$ radiation $(\lambda=1.54060 \AA)$ at an angle of $2 \Theta$.

\section{Results and Discussion}

\section{A. Data on XRD and Mineral Phases at Batuaan Granit Kuta Blang Village}

From the results of X-ray Diffraction tests and analyzes conducted on samples of the Granite of Kuta Blang Village, the data were obtained as shown in Table 1, while the diffraction system of mineral phase as shown in Figure 2. The Result shown there are 3 highest peaks called the major

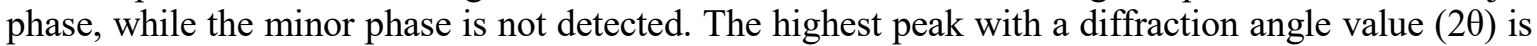
27.5829 , and then the distance between fields (d) is 3.23128 , and the intensity value (I) 100 . Then the second highest peak is continued with the diffraction angle value (20) 26.6527, then the distance between fields (d) which is 3.34191 , and the intensity value (I) 58 . And the third highest peak is the

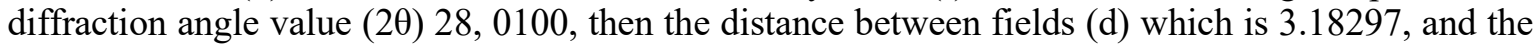
intensity value (I) is 38 . While the mineral phase is based on that sequence which are : $\mathrm{C}_{16} \mathrm{AlClN}_{16} \mathrm{~S}_{4}, \mathrm{O}_{2} \mathrm{Si}$, and $\mathrm{F}_{15} \mathrm{Mo}_{5} \mathrm{O}_{15} \mathrm{Rb}_{15}$. 
Tabel 1. Data on XRD and Mineral Phases at Batuan Granit Kuta Blang Village

\begin{tabular}{ccccc}
\hline No & $2 \Theta\left({ }^{\circ}\right)$ & $\mathrm{d}\left(A^{\circ}\right)$ & $\mathrm{I}$ & Phases Mineral \\
\hline 1 & 27.5829 & 3.23128 & 100 & $\mathrm{C}_{16} \mathrm{AlClN}_{16} \mathrm{~S}_{4}$ \\
2 & 26.6527 & 3.34191 & 58 & $\mathrm{O}_{2} \mathrm{Si}$ \\
3 & 28.0100 & 3.18297 & 38 & $\mathrm{~F}_{15} \mathrm{Mo}_{5} \mathrm{O}_{15} \mathrm{Rb}_{15}$ \\
\hline
\end{tabular}

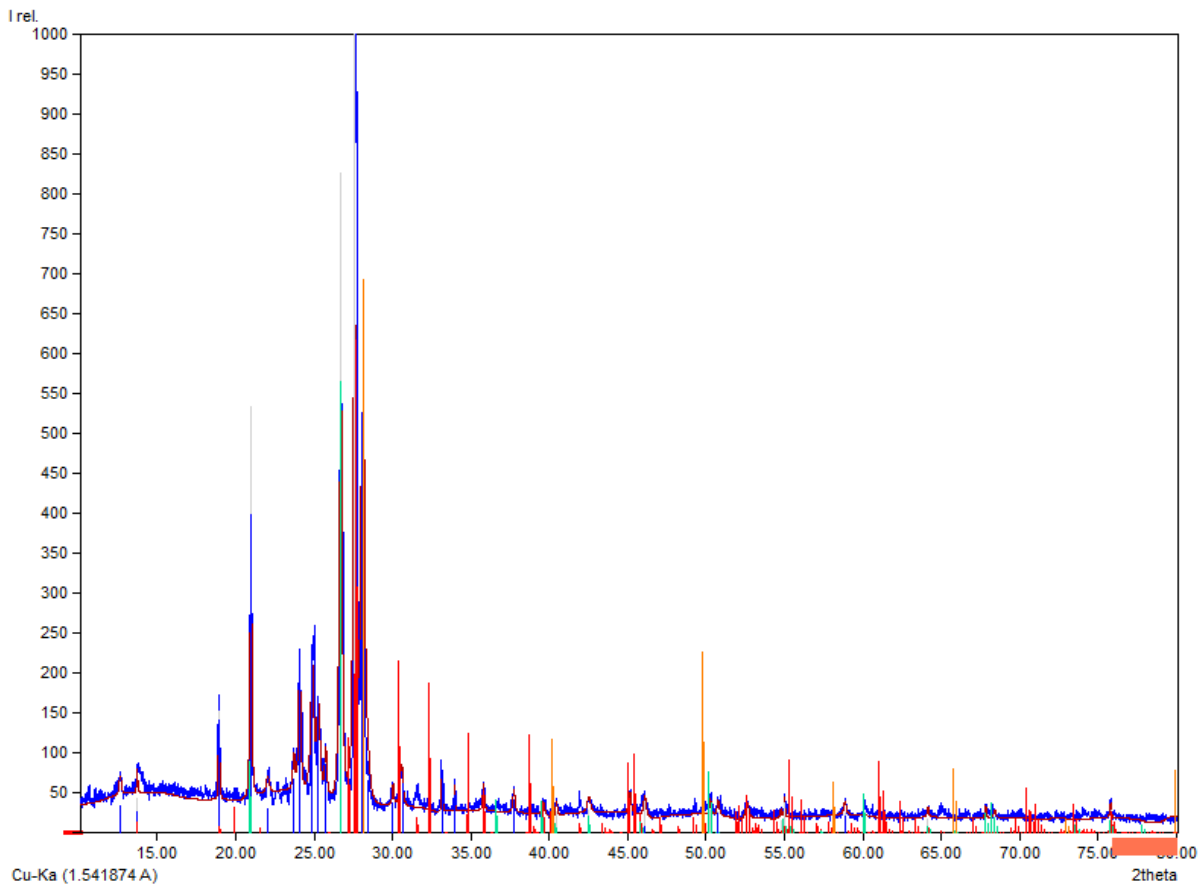

Figure 4. X-ray diffraction system samples of granite rock from Kutablang Village

\section{B. Data on XRD and Mineral Phases in Batuaan Granite, Lubuk Layu Village}

From the results of X-ray Diffraction test and analysis conducted on granite rock samples Lubuk Layu Village is almost the same as Kutablang Village, while the data obtained are as shown in Table 1. Then the mineral phase diffraction pattern can be seen in Figure 2 . The result shown, there are 3 highest peaks called by major phases, and the minor phase is undetectable. The highest peak with a

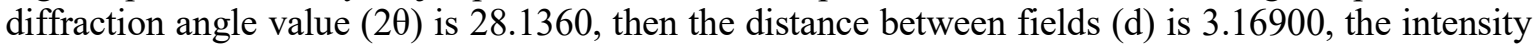
value (I) 100 , with the $\mathrm{O}_{2} \mathrm{Si}$ constituent minerals. Then the second highest peak is continued by the

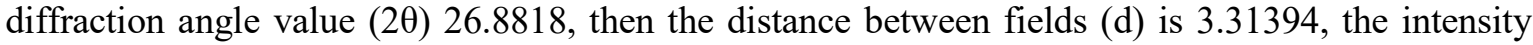
value (I) 79, and the mineral phases are $\mathrm{F}_{15} \mathrm{Mo}_{5} \mathrm{O}_{15} \mathrm{Rb}_{15}$, and the third highest peak is the diffraction angle value ( $2 \theta$ ) 27.7400 , then the distance between fields (d) is 3.21334 , the intensity value (I) 38 , and the constituent mineral phase are $\mathrm{La}_{2} \mathrm{Mo}_{2} \mathrm{O}_{9}$.

Tabel 2. Data on XRD and Mineral Phases of Granite Rocks at Lubuk Layu Village

\begin{tabular}{ccccc}
\hline No & $2 \Theta\left({ }^{\circ}\right)$ & $\mathrm{d}\left(A^{\circ}\right)$ & $\mathrm{I}$ & Phases Mineral \\
\hline 1 & 28.1360 & 3.16900 & 100 & $\mathrm{O}_{2} \mathrm{Si}$ \\
2 & 26.8818 & 3.31394 & 79 & $\mathrm{~F}_{15} \mathrm{Mo}_{5} \mathrm{O}_{15} \mathrm{Rb}_{15}$ \\
3 & 27.7400 & 3.21334 & 38 & $\mathrm{La}_{2} \mathrm{Mo}_{2} \mathrm{O}_{9}$ \\
\hline
\end{tabular}




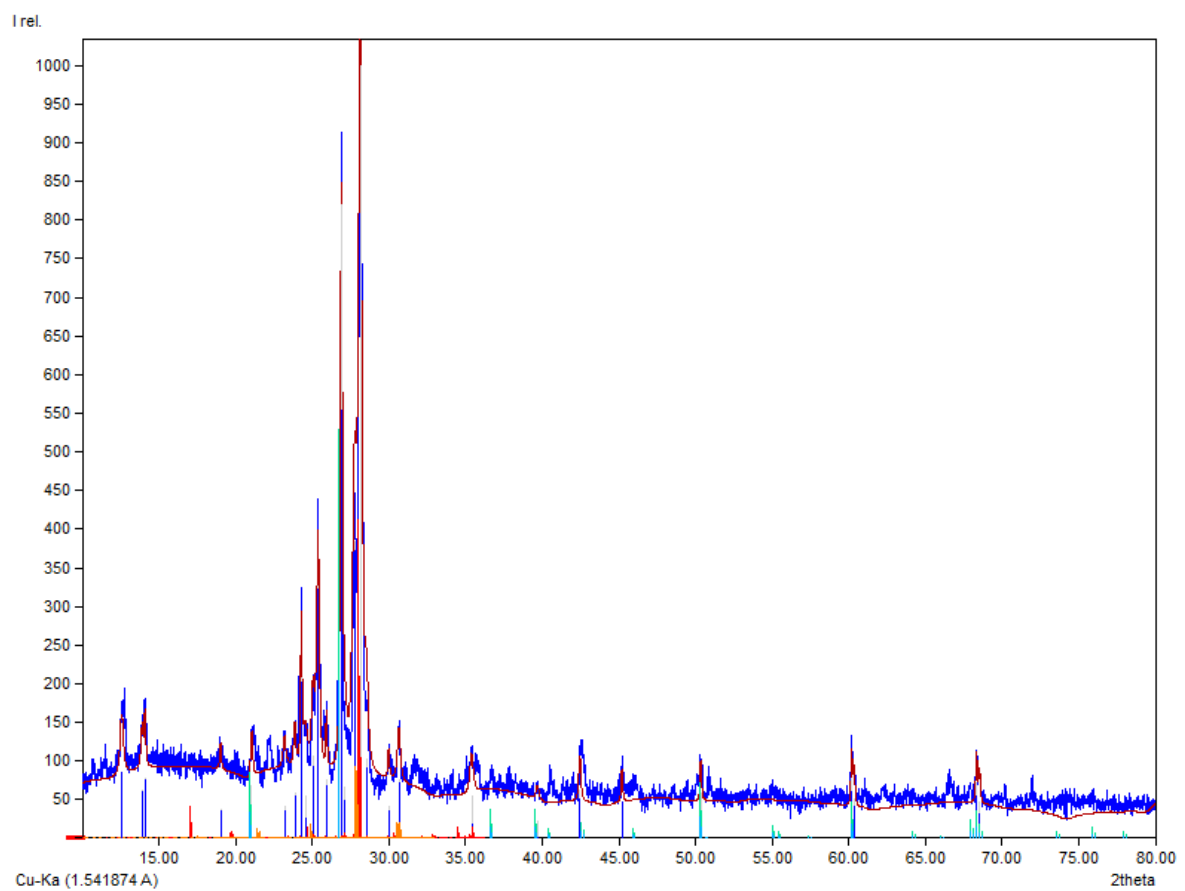

Figure 5. X-ray diffraction system of granite rock samples from Lubuk Layu Village

\section{Conclusion}

From the results of field observations in determining samples using GPS (Ground Check), a map of the location of granite rocks was obtained from two different locations, which are Lubuk Layu Village and Kuta Blang Village. The data processing is done by using X-rays on both rock samples, each of sample has three main mineral phases as constituents, and in both samples shows there is one phase of the same mineral, which is $\mathrm{O}_{2} \mathrm{Si}$ (Silicon Oxide Quartz).

\section{Acknowledgment}

The author would like to thank to the Polytechnic of South Aceh for funding this research through the program "Penelitian Hibah Mandiri tahun 2018".

\section{References}

[1] Bayrak, G. \& Yilmaz, S., 2014. Granit Based Glass-Ceramic Material. Antalya, Turkey, ACTA PHYSICA POLONICA A.

[2] Oktamuliani, S., S., MZ, N. \& N., 2015. Identifikasi Mineral Pada Batuan Granit di Geopark Merangin Provinsi Jambi Menggunakan X-Ray Diffaction (XRD) dan Scanning Electron Microscopy. JoP, 1(No.1), pp. 12-17.

[3] Badan Pusat Statistik Aceh Selatan, 2017. Aceh Selatan Dalam Angka. 1102001.1103 ed. Aceh Selatan: Katalog.

[4] Bajili, A., Hamdi \& Dwiridal, L., 2014. KARAKTERISASI MINERAL PADA BATU GRANIT DI SEKITAR GUNUNG MARAPI DAERAH SUMATERA BARAT MENGGUNAKAN X-RAY DIFFRACTION (XRD). PILLAR OF PHYSICS, Vol. 1., pp. 01-08.

[5] Dhanapandian, S., Gnanavel, B. \& Ramkumar, T., 2009. Utilization of Granite and Marble Sawing Powder Wastes as Brick Material. Carpathian Journal of Earth Environmental Sciences, 4(No. 2), pp. $147-160$ 
[6] Juliansyah, Ratnawulan, and A. Fauzi, "Pengaruh Temperatur Kalsinasi Terhadap Struktur Mineral Granit Yang Terdapat di Nagari Surian Kecamatan Pantai Cermin Kabupaten Solok," Pillar Phys., vol. 6, pp. 9-16, 2015. 